\title{
HANES 法による數種の糖の定量に就て
}

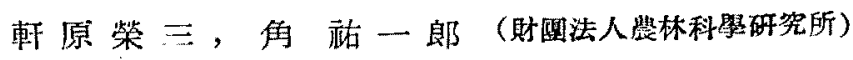

昭和 25 作 2 月 14 日受理

On the Determination of Reducing Sugars by HANES' Method.

By Eizó Nokinara and Yûichiró Sumí (Agricultural and Forestal Science Laboratory)

筹者等は Glucose, Galactose, Mannose 及び Xylose を定量する必要を生じ，その方法として簡易・正確、 な HANES(1) 法を用いる事にしたが，從來の定量值はまちまちであるので,先ず標集定量值を求める必要がある.

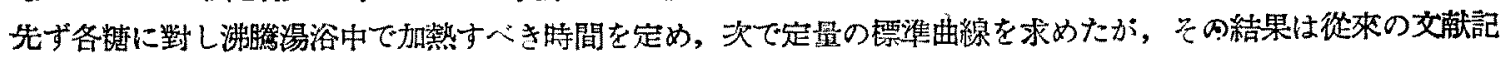
載の data とは些か晎る值が得られたので報告する。

從來 HANES 法乃至々の改呈法, 若くは HANES 法の原法である HAGEDORN-JENSEN 法を用いて各種の

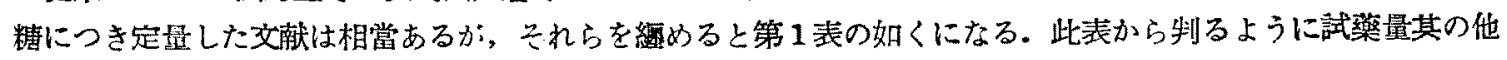
の條件によつて可成り值に差がある。

Table 1. Disagreement in Reducing Power of Each Sugar in $\mathrm{K}_{3} \mathrm{Fe}(\mathrm{CN})_{6}$ Oxidation in Literetures

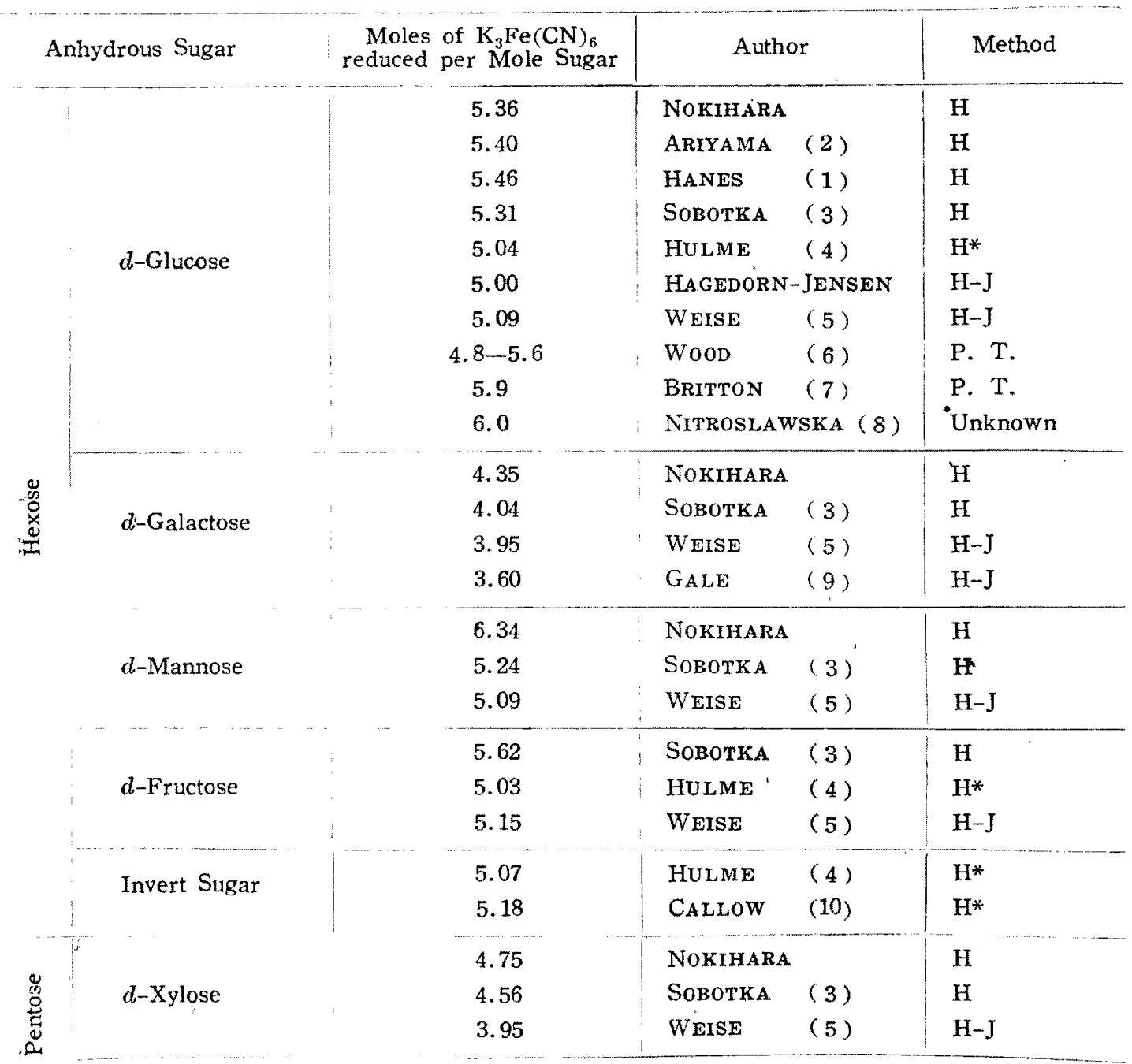




\begin{tabular}{|c|c|c|c|c|c|}
\hline \multirow{3}{*}{ 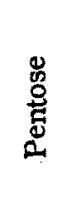 } & l-Arabinose & $\begin{array}{l}4.18 \\
3.72\end{array}$ & $\begin{array}{l}\text { SoBOTKA } \\
\text { WEISE }\end{array}$ & $\begin{array}{l}(3) \\
(5)\end{array}$ & $\begin{array}{l}\mathrm{H} \\
\mathrm{H}-\mathrm{J}\end{array}$ \\
\hline & $d$-Ribose & 3.58 & SoBOTKA & (3) & $\mathrm{H}$ \\
\hline & $l$-Rhamnose & 5.02 & SовоткA & (3) & $\mathrm{H}$ \\
\hline \multirow{6}{*}{ 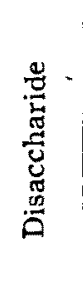 } & \multirow{4}{*}{ Maltose } & 7.94 & HANES & (1) & $\mathrm{H}$ \\
\hline & & 8.44 & Sовотка & (3) & $\mathrm{H}$ \\
\hline & & 7.18 & Hulme & (4) & $\mathrm{H}^{*}$ \\
\hline & & 7.35 & WeIse & (5) & $\mathrm{H}-\mathrm{J}$ \\
\hline & \multirow{2}{*}{ Lactose } & 7.92 & SовоTKA & (3) & $\mathrm{H}$ \\
\hline & & 6.77 & WEISE & (5) & $\mathrm{H}-\mathrm{J}$ \\
\hline
\end{tabular}

Note 1.

H: HANES' method

H-J: HAGEDORN-JENSEN'S method

$H^{*}$ : Modified HaNes' method

P.'Г.: Potentiometric titration

Note 2. Since the amounts of sugar and $\mathrm{K}_{3} \mathrm{Fe}(\mathrm{CN})_{6}$ reduced are not precisely proportional in the range of determinations, the above values are approximate.

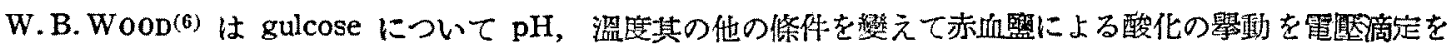
用い研究したが，尗によると，先す S $\phi$ RENSEN の $0.1 M$ glycocol- $\mathrm{NaOH}$ 緩衝液を用い $\mathrm{pH}$ を變えた次の 6 種につき行つた。

Table 2 Effect of $\mathrm{pH}$ for Reducing Power of $d$-Glucose in $\mathrm{K}_{3} \mathrm{Fe}(\mathrm{CN})_{6}$ Oxidation (dy Wood)

\begin{tabular}{|c|c|c|c|}
\hline & $\begin{array}{c}0.1 M \\
\text { Glycocol }\end{array}$ & $\begin{array}{l}0.1 M \\
\mathrm{NaOH}\end{array}$ & $\begin{array}{c}\text { Final oxidant reduced } \\
(\text { after } 20 \mathrm{mins}) \\
\left(M \text { oles } \mathrm{K}_{3} \mathrm{Fe}(\mathrm{CN})_{6}\right. \\
\text { reduced per } M \text { ole glucose })\end{array}$ \\
\hline I & 0 parts & 10 parts & ca. 4.8 \\
\hline II & $1 /$ & $9 / 1$ & II 4.95 \\
\hline III & 211 & 811 & " 5.05 \\
\hline N & $2.5 \prime \prime$ & $7.5 \prime \prime$ & "I 5.19 \\
\hline $\mathrm{Y}$ & 3. 11 & $7 \prime \prime$ & " 5.35 \\
\hline YI & $3.5 \prime \prime$ & 6.5 & $">5.5$ \\
\hline
\end{tabular}

关の酸化の棈子はアルカリ性が强く なる程最初の反應速度は速いが，速に

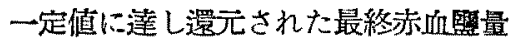
は少い.之に對しアルカッ性が弱くな るに從い反㗹速度は遲くなり，徐へに 赤血監を消费してゆくが，二の最終消 费遗はアルカリ性の强い境合上り多く なる.罚道については第 2 表 II の條 俳で $100^{\circ}$ と $95^{\circ}$ にいて行つている が, $\mathrm{pH}$ 變化の場合と同㧺な效果が認 められ，溫度が低い恃法反隹速度は遲 いが最終還元赤血照舆は $100^{\circ}$ の場合

上り多くなり，兩温度では最終值に於て一致が見られないと云う。

HANES 法では一定組成の A 溜 $\left[\mathrm{K}_{3} \mathrm{Fe}(\mathrm{CN})_{6}+\mathrm{Na}_{2} \mathrm{CO}_{3}\right]$ を用いて酸化するのであるから $\mathrm{pH}$ の條件は同一

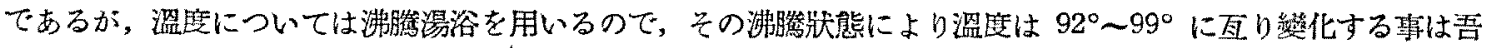

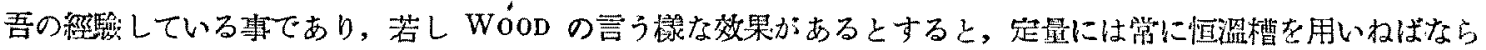

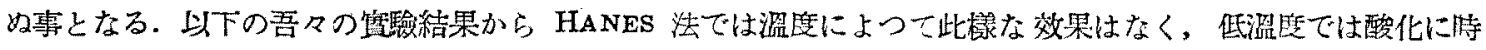
間を要するが最終酸化程度は同じである事を知つた。

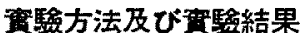

\section{(1) 使用供試糙}

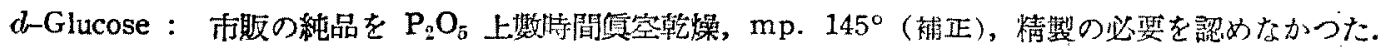

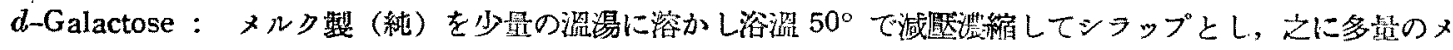

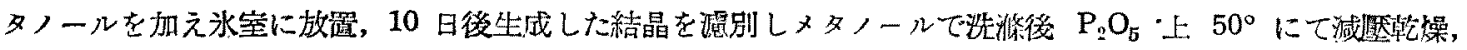
mp. $166^{\circ}$ (鬴正)

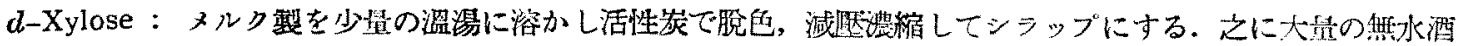




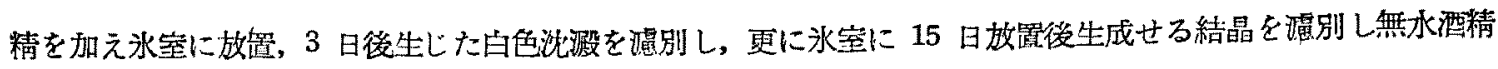
て洗源後 $\mathrm{P}_{2} \mathrm{O}_{\tilde{5}}$ 上減㟲乾燥する $\left(50^{\circ}\right) \mathrm{mp} .144^{\circ}$ (補正).

d-Mannose：メルク製を荒木民の方法(11)により hydrazon を經て benzaldehyde で mannose を再生し

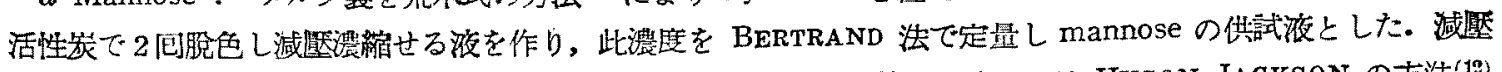

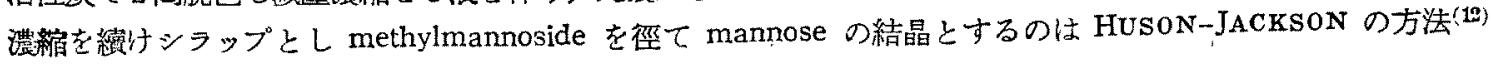

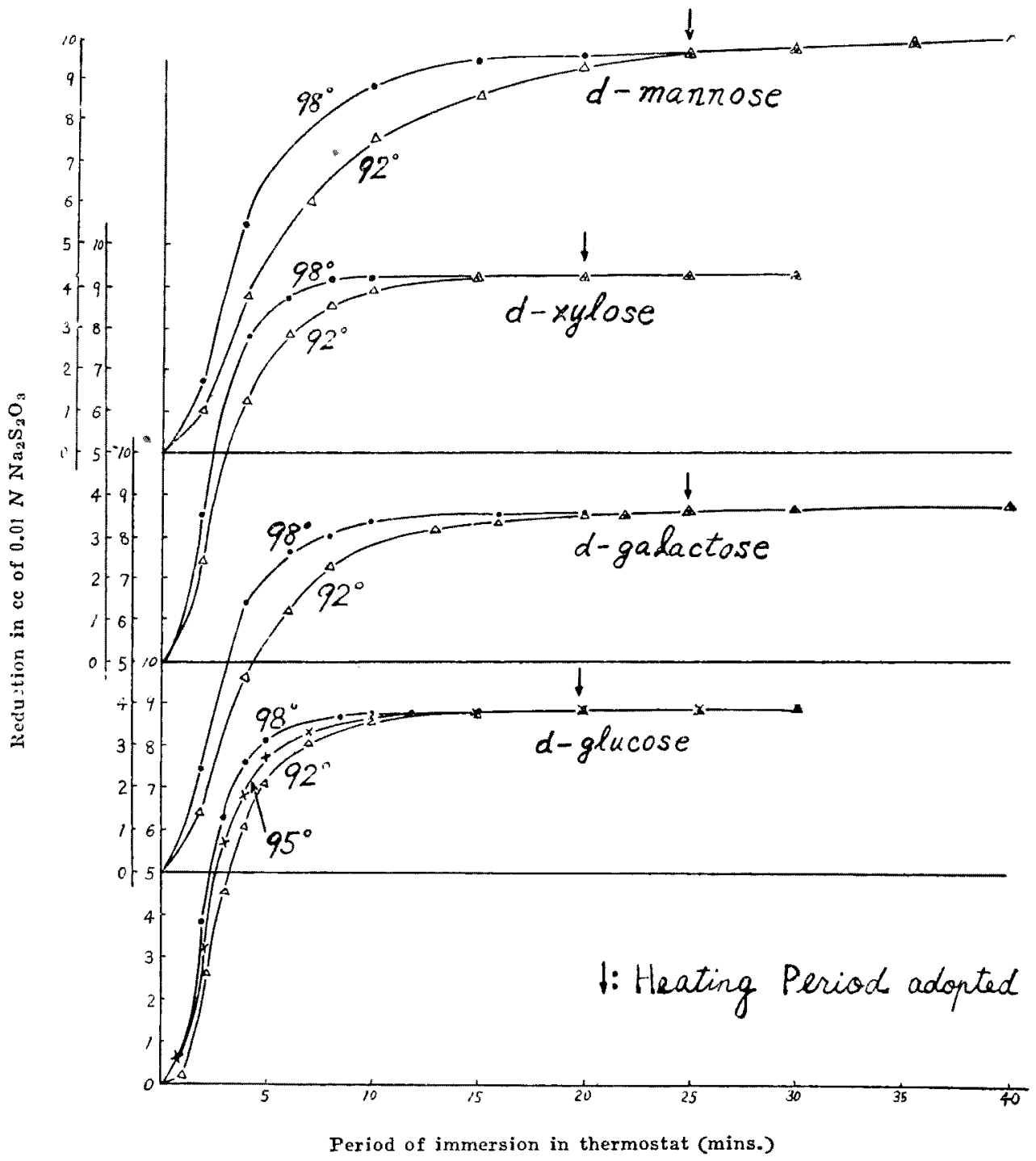

Fig. 1 Determination of heating period adopted for each sugars

により目下製造中である.

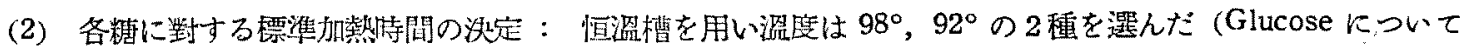

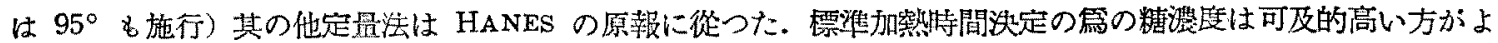
いので. $0.01 \mathrm{~N} \mathrm{Nan} \mathrm{S}_{2} \mathrm{O}_{3}$ 約 $9 \mathrm{cc}$ に相當する糖婊度で行つた。結果は第 1 圆の如くである.これから判る如く

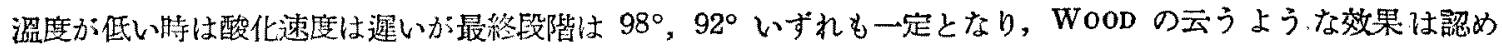
られない。從つて定冒に祭しては大賀沸騰してい机 Glucose, Xylose に對しては 20 分, Galactose, Mannose に對しては 25 分加算寸层い。

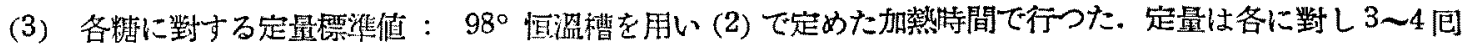


宛施行しその本均をとつた。. 結果は第 3 表及び第 2 圆の如くである. 此の結果から Glucose, Galactose, Xylose

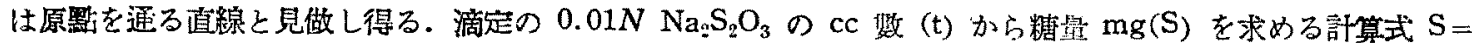
a.t $の$ a を最小目乘法により求めると

$$
\begin{array}{ll}
d-\text { Glucose } & S=(0.3364 \pm 0.0006) \mathrm{t}, \quad d-G \text { alactose } S=(0.4135 \pm 0.0004) \mathrm{t} \\
d \text {-Xylose } & S=(0.3160 \pm 0.0001) \mathrm{t}
\end{array}
$$

である. Mannose は䉷密には直線でなく中凸であるが直線と見做して計算すると

$$
d \text {-Mannose } \quad S=(0.2836 \pm 0.0015) t
$$

である.

Table 3 Standardization Values for Each Sugars

\begin{tabular}{l|c|c|c||c|c||c|c}
\hline \multicolumn{2}{l}{$d$-Glucose } & \multicolumn{2}{c|}{$d$-Galactose } & \multicolumn{2}{c||}{$d$-Xylose } & \multicolumn{2}{c}{$d$-Mannose } \\
\hline $\mathrm{S}$ & $\mathrm{t}$ & $\mathrm{S}$ & $\mathrm{t}$ & $\mathrm{S}$ & $\mathrm{t}$ & $\mathrm{S}$ & $\mathrm{t}$ \\
\hline 0.40 & 1.15 & 0.435 & 1.20 & 0.374 & 1.19 & 0.375 & 1.305 \\
0.80 & 2.34 & 0.87 & 2.08 & 0.748 & 2.35 & 0.749 & $2 \cdot 57$ \\
1.20 & 3.58 & 1.30 & 3.17 & 1.122 & 3.56 & 1.124 & 3.92 \\
1.60 & 4.68 & 1.74 & 4.24 & 1.496 & 4.74 & 1.498 & 5.26 \\
2.00 & 5.93 & 2.17 & 5.24 & 1.870 & 5.94 & 1.873 & 6.66 \\
2.40 & 7.16 & 2.61 & 6.37 & 2.244 & 7.10 & 2.247 & 8.10 \\
2.80 & 8.37 & 3.04 & 7.36 & 2.618 & 8.27 & 2.622 & 9.48 \\
3.20 & 9.51 & 3.47 & 8.35 & 2.992 & 9.46 & & \\
& & 3.91 & 9.45 & & & & \\
& & 4.35 & 10.50 & & & & \\
\hline
\end{tabular}

$\mathrm{S}$ : $\mathrm{mg}$ of sugar in $5 \mathrm{cc}$ solution

$t$ : cc of $0.01 N \mathrm{Na}_{2} \mathrm{~S}_{2} \mathrm{O}_{3}$ for reduced $\mathrm{K}_{3} \mathrm{Fe}(\mathrm{CN})_{6}$

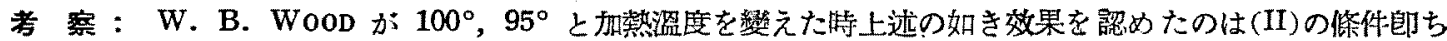
$0.1 M$ Glycocol 1 部, $0.1 M \mathrm{NaOH} 9$ 部の緩衝液でアルカリ性が極めて强い場合である. 且气の Glucose $1 \mathrm{Mol}$

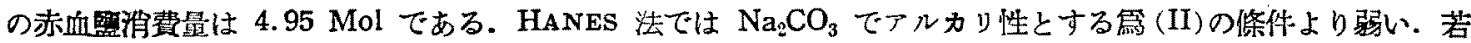

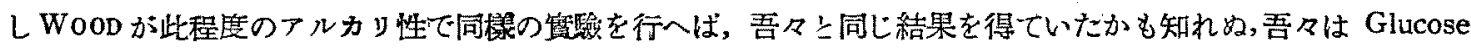
$1 \mathrm{Mol}$ に對する赤血盟量は $5.36 \mathrm{Mol}$ と得たが，之は WOOD の算驗では(V)に相當する. HANES 法に於ける $\mathrm{Na}_{2} \mathrm{CO}_{3}$ のアルカリ生忙此の(V)の程度ではなからうか。

夷に Glucose, Xylose では從來の交献と大差ない結果を得たが, Galactose, Mannose については SoBo-

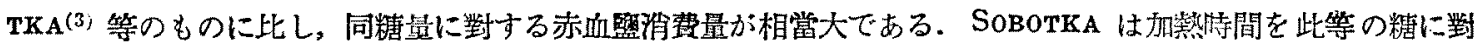
しても一稳に 15 分としたと思える (篚考推定). Glucose, Xylose の埸合は 15 分でも大體一定値に達するが，

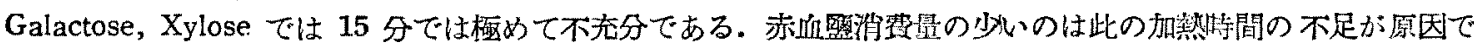

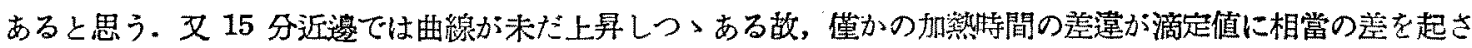

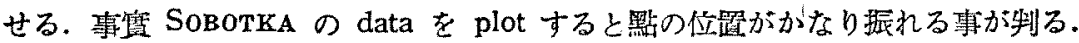

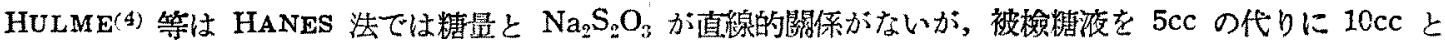
すれば(他の條件は凡て同じで) 次の如き直緗關係が得られるとし

$$
\begin{aligned}
& \mathrm{S}=\mathrm{b}(\mathrm{T}+\mathrm{a}) \quad \mathrm{S}: \mathrm{mg} . \text { of sugar in } 10 \mathrm{cc} \text { solution } \\
& \mathrm{T}: \text { Observed } 0.01 \mathrm{~N} \text {-thiosulfate } \mathrm{cc}
\end{aligned}
$$

例えば Glucose に對する a,b の値は夫及 $0.05 ， 0.340$ であるとした。併し吾マは $5 \mathrm{cc}$ を用いても Glu-

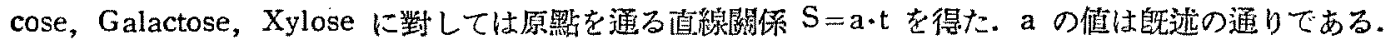

要 旨：1) $d$-Glucose, $d$-Galactose, $d$-Xylose, $d$-Mannose の4種の還元糖につき HANES 法で定量 する際の䅺準加矪特間, 標準定显曲線, 定照式を求めた。

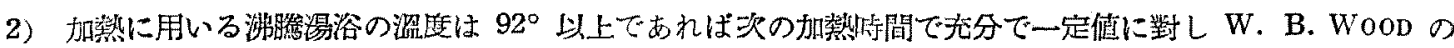




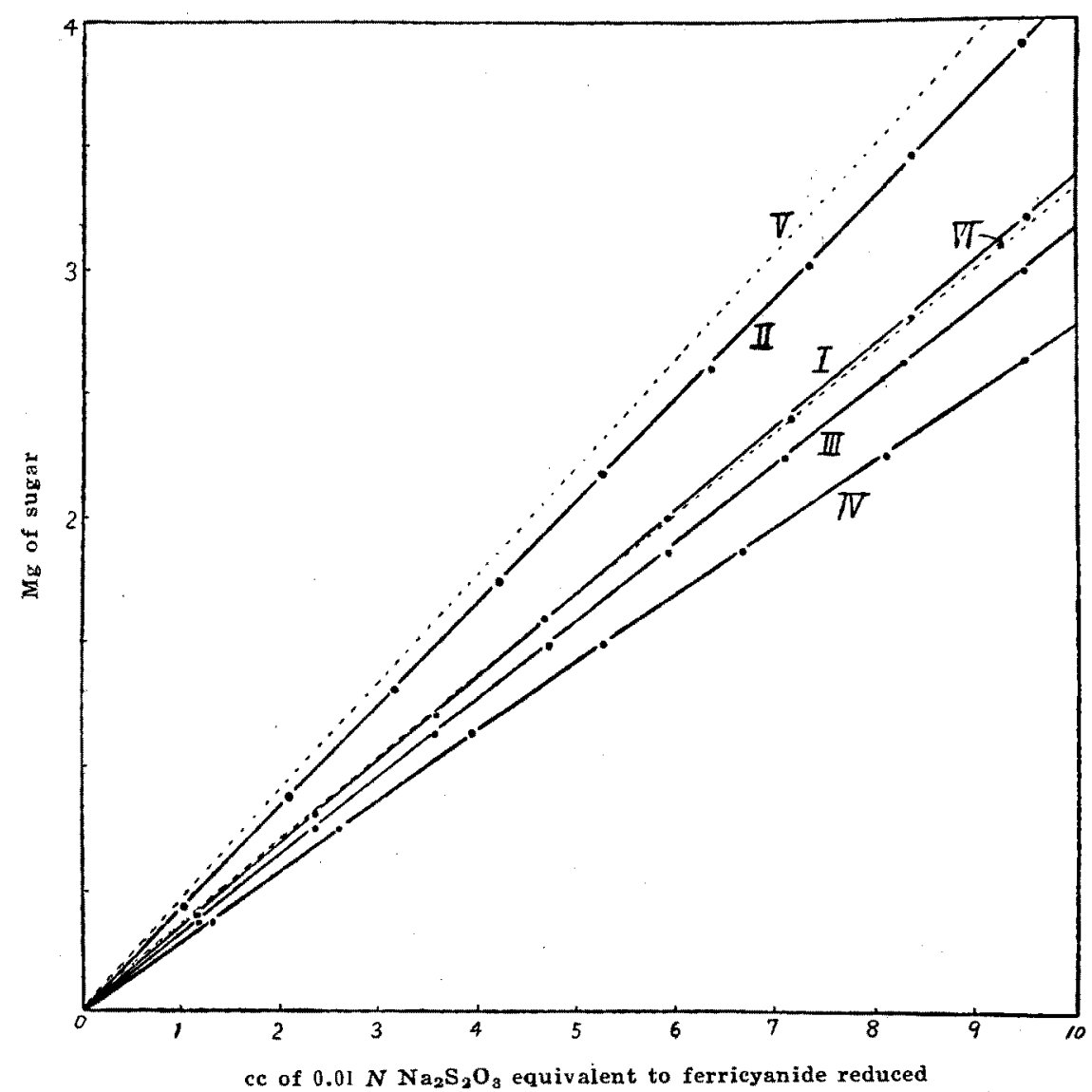

Fig. 2. Standard Graph for Determination of Each Sugars

$\begin{aligned} \text { I }: & \text { Ánhydrous } & d \text {-Glucose } & \text { IV }: \text { Anhydrous } d \text {-Mannose } \\ \text { II }: & \prime \prime & d \text {-Galactose } & \text { V }: d \text {-Galactose (SoBotKA) } \\ \text { III }: & \prime \prime & d \text {-Xylose } & \text { VI }: d \text {-Mannose }(")\end{aligned}$

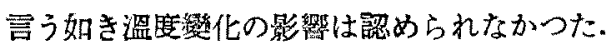

Glucose, Xylose $\cdots 20$ 分, Galactose, Mannose...25 分

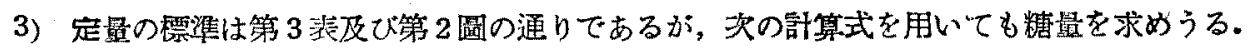

$$
\begin{array}{llll}
d-\text { Glucose } & S=(0.3364 \pm 0.0006) \mathrm{t} & \quad d \text {-Xylose } & S=(0.3160 \pm 0.0001) \mathrm{t} \\
d-\mathrm{G} \text { alactose } & \mathrm{S}=(0.4135 \pm 0.0004) \mathrm{t} & d \text {-Mannose } & S=(0.2836 \pm 0.0015) \mathrm{t}
\end{array}
$$

$\mathrm{S}$ : 溶液 $5 \mathrm{cc}$ 中糖量 $\mathrm{mg}$

$\mathrm{t} ：$ 瞢元された赤血傿に相賞する $0.01 N \mathrm{Na}_{2} \mathrm{~S}_{2} \mathrm{O}_{3} \mathrm{cc}$

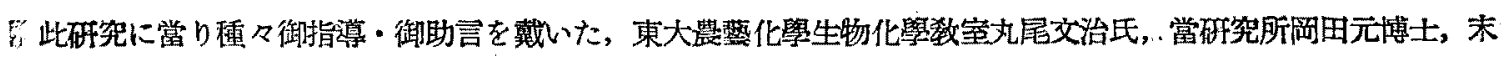
弘女史, 三川圌氏始め其の他の所員に感謝の意を㸞す。

(1) C. S. HANES : Biochem. J., 23, 99 (1929)

(2) 有山登：化學定臉學，筷 II 部 12, ${ }^{\wedge}$ P.296

(3) H. SobotKA and M. ReINeR : Biochem. J., 24, 394 (1930)

(4) A.C. HULME and R. NARAIN : ibid., 25, 1051 (1931)

(5) W. WEISE and Th. v. BRA.ND : Biochem. Z., 264357 (1933)

(6) W. B.WooD : J. Biol. Chem., 110, 219 (1935)

(7) H. T. S. Britton and L. Phillips : C.A. 34, 2734 ; Analyst, 65, 149 (1940)

(8) W. Nitroslawska: C. A., 23, 5206 
(9) E. F. GALE : Biochem. J., 31, 234 (1930)

(10) E. H. CaLlow : ibid., 24, 57 (1930)

(11) 荒木： 化學筫龭學，第 II 部 11, P.154

(12) C. S. HudSON and E. L. JACKson : J. Amer. Chem. Soc., 56, 958 (1934)

Summery

In the determination of $d$-glucose (I), $d$-galactose (II), $d$-mannose (III) and $d$-xylose (IV) (all sugars are anhydrous) by the Hanes' method, reducing value of each sugar for ferricyanide reaches a constant value after the following heating period, if the temperature of boiling water-bath is above $92^{\circ}$ :(I) and (IV) $\cdots 20 \mathrm{~min} .$, (II) and (III) $\cdots 25 \mathrm{~min}$. Hence, this period of heating must be used as standard in the determination. W. B. Woon's result, that lowering of temperature of boiling waterbath causes an increase in the final amount of oxidizing agent reduced, was not ascertained in our present investigation. The formula $s=a \cdot t$, where $s$ and $t$ are $\mathrm{mg}$ of sugar in $5 \mathrm{cc}$ solution and $\mathrm{cc}$ of $0.01 \mathrm{~N} \mathrm{Na}_{2} \mathrm{~S}_{2} \mathrm{O}_{3}$, respectively, was established for each sugar ; values of $a$ for (I), (II), (III) and (IV) are $0.3364 \pm 0.0006,0.4135 \pm 0.0004,0.2836 \pm 0.0015$ and $0.3160 \pm 0.0001$, respectively.

\section{[ERRATA]}

J. Agr. Chem. Soc. Vol. 23

\begin{tabular}{|c|c|c|c|c|}
\hline \multicolumn{2}{|c|}{ Page } & Line & For & Read \\
\hline 56 & & 2 & protains & proteins \\
\hline$" \prime$ & & 4 & content are & contents are \\
\hline$\prime \prime$ & & 18 & tcientific & Scientific \\
\hline 60 & Sum. & 7 & qualities & quantities \\
\hline$" \prime$ & " & 8 & Starch & Starches \\
\hline$" \prime$ & " & 12 & stump & strain \\
\hline$\prime \prime$ & "l & " & micrologically & microbiologically \\
\hline 65 & Sum. & -1 & $3.25 \%$ & $8.25 \%$ \\
\hline 68 & & -4 & Renort & Report \\
\hline 80 & & -5 & by malt saccharified & malt-saccharified \\
\hline 85 & Sum. & 2 & $k o i j$ & $k o j i$ \\
\hline$\prime \prime$ & $\prime \prime$ & 4 & are & were \\
\hline 89 & Sum. & -3 & shaked & shaken \\
\hline$\prime \prime$ & " & " & atomosphere & atmosphere \\
\hline 91 & " & 5 & Few & A few \\
\hline$\prime \prime$ & " & 9 & acts & acted \\
\hline 95 & $\prime \prime$ & -1 & is indirubin & was indirubin \\
\hline$\prime \prime$ & $\prime \prime$ & $" 1$ & is indigo & was indigo \\
\hline 101 & $" \prime$ & $1 \sim 2$ & pointed out that & pointed out \\
\hline$\prime \prime$ & " & 2 & orwinding & or winding \\
\hline 107 & & 7 & Shoihi & Shoichi \\
\hline 110 & Sum. & 4 & and next putrescible, corn & $\begin{array}{l}\text { and the transparent starch and } u k i k \bullet \text { are } \\
\text { putrescible in the next degree }\end{array}$ \\
\hline
\end{tabular}

N. B. Line numb er with the sign-should be calculated from beneath. Sum. is for the part of Summary. 


\section{Analysis of Quercetin and Its 3-Glycosides by Paper Partition Chromatography}

Sir :

Owing to the resemblance of the chemical structure, solubility, and spectrum, it is difficult to separate and determine quercetrin, isoquercitrin (quercetin-3-glucoside prepared from leaves of mulberry), quercitrin (quercetin-3-rhamnoside), and rutin (quercetin-3-rhamno-glucoside from buckwheat).

But we have obtained good results in the analysis of these flavonoid pigments by paper partition chromatography.

The method employed is as follows :

1) In the one-dimensional descending chromatography, strips of filter paper "Toyo No.4" $(2 \times 40 \mathrm{~cm}$. $)$ were used.

2) The best developing solvent was the water-rich layer of the three component system, consisting of 50 parts ethyl acetate, 2 parts glacial acetic acid, and 50 parts distilled water.

3) The saturated aqueous solution of basic lead acetate was used as the colouring reagent and the spots were observed under ordinary and ultraviolet lights.

The Rf values of these flavonoid pigments obtained in this experiment were as follows : quercetin 0.80 , quercitrin 0.67 , isoquercitrin 0.43 , and rutin 0.10 .

When yellow precipitates obtained by decomposition of these glycosides with dilute $\mathrm{H}_{2} \mathrm{SO}_{4}$ were chromatographed, the spot of quercetin, the aglycone of these glycosides, was detected.

'The solution obtained by filtering off the yellow precipitates was neutralized and concentrated in vacuo, and the sugars in this concentrate were chromatographically analysed. We detected glucose from isoquercitrin, rhamnose from quercitrin and both of these sugars from rutin on chromatograms by PARTRIDGE's method [Nature, 164, 443, (1949)].

An alcoholic solution of rutin was incompletely decomposed by dilnte $\mathrm{H}_{2} \mathrm{SO}_{4}$ and neutralized. By the chromatographic analysis of this solution, isoquercitrin was detected. From this fact, it was proved that the disaccharide combined at 3-position of rutin was rhamno-glucoside.

These flavonoid pigments extracted from 10 to 20 spots of chromatograms were identified with original flavonoids by spectral analysis.

It was an interesting fact that the Rf values of these glycosides were parallel to those of the corresponding sugars.

\begin{tabular}{l|c||l|c}
\multicolumn{1}{l|}{ Flavonoids } & Rf value & Sugars & Rf value \\
\cline { 1 - 3 } & 0.10 & Disaccharide Lactose & 0.10 \\
Rutin & 0.43 & Glucose & 0.12 \\
Isoquercitrin & 0.67 & Rhamnose & 0.21 \\
Quercitrin & & 0.39 \\
\hline
\end{tabular}

In other words, solubilities of these flavonoid pigments depend on the nature of sugars combined at 3-position.

Biochemical Laboratory,

Faculty of Agricuiture, Kyushu University, Fukuoka 